\title{
Effect of agrotechnical factors on the yield of the Grolim asparagus (Asparagus officinalis L.) hybrid on acidic sandy soil
}

\author{
Zsuzsa Erdős \\ University of Debrecen, Institutes for Agricultural Research and Educational Farm Research, \\ Institutes of Nyíregyháza, Nyíregyháza \\ erdoszs@agr.unideb.hu
}

SUMMARY

Research of blanched asparagus has begun at the University of Debrecen Institutes for Agricultural Research and Educational Farm Research Institutes of Nyiregyháza in 2011. Establishment of the plantation took place in May 2011. The Grolim hybrid was used in the trial, 16 medium plot trial area has been formed under field conditions, with four repetitions and $36 \mathrm{~m}^{2}$ plot size. In the course of our studies, the effect of different nutriment supply methods (untreated, manure, sheep manure compost, fertilizer) has been analysed on the spear yield of the Grolim asparagus hybrid between 2013 and 2017.

In our studies, the beginning of vegetative growth has been recorded upon the constant presence of $10{ }^{\circ} \mathrm{C}$ of average soil temperature in the case of the Grolim asparagus hybrid. The beginning and length of spear harvesting are both influenced by the time and dynamics of initial development in spring. During the analysed period, the dates of spear harvesting were various, the earliest being on $23^{\text {rd }}$ March, 2014 and the latest on $23^{\text {rd }}$ April, 2015; the rest of the three years have been varied within this one month interval. The total of heat units required for the vegetative development of spears has been determined; it provides important information for cultivation practice.

Spear yields turned out to be hectic during the analysed period. In 2013 and 2014, yields have surpassed the amount of $50 \mathrm{~kg} / \mathrm{harvest}$ period/plot in the case of every treatment version. However, in 2015 a significantly lower specific yield has been recorded due to the unfavourable weather conditions in spring; a yield decline of nearly 50\% was recorded in the case of the control treatment compared to the previous years. Yield was also lower in the rest of the fertilization treatments compared to 2014; however, in these cases, the degree of yield decrease was around 5-10\%, which suggests the yield stabilising effect of fertilization. In 2016, a slight yield increase was measured in comparison with the base year. In 2017, there was a decline of yield in the control treatment; however, the different fertilization treatments resulted in yield increase as compared to previous years.

On the basis of our studies, it is clear that the best yield results have been provided by the artificial fertilization treatment in all of the five analysed years. It was followed by the sheep manure compost and manure treatments in terms of their effect on spear yield. During the three harvesting periods, the lowest yield on acidic sandy soil was recorded in the case of the control treatment. The most remarkable effect of nutriment treatments has been realised in terms of the decreased deviation of yield results, which perfectly represents the yield stabilising effect of nutriment supply in the case of perennial crops - asparagus - as well, even on a poor nutriment supply characteristic sandy soil.

Keywords: cropyear, asparagus, acidic sandy soil, fertilization methods, yield

\section{INTRODUCTION}

The origin of asparagus (Asparagus officinalis L.) can be traced back to 2500 years, which is verified by a number of preserved written records. Asparagus species, which are nowadays utilised in public production, were probably known and consumed by the ancient Egyptians. It was a popular meal in the Roman Empire a few hundred years ago B.C. For ancient Greeks, asparagus was considered not only as an essential nutritional item, but also as a medicine and as a cleansing material for the human body. Wild varieties of asparagus plant are indigenous in both Asia and Europe. In Europe, the following wild and domesticated varieties have become the most widespread: Asparagus acutifolius, A. tenuifolius, A. maritimus or A. officinalis which is cultivated on the largest area (Cerne et Kacjan Marsic 2002).

Asparagus is a perennial crop that is able to grow for 15 to 20 years following planting, but in intensive cultivation, this period is limited to $10-12$ years. The strong roots of the plant make it possible for the asparagus spears to be economically harvested without the complete depletion of the root system, but at the same time, it is important for the production area to always have sufficient amount of nutrients (Pressman et al. 1993, Drost 1997, Fehérné 2005).

One of the earliest vegetable crops is asparagus, harvesting season lasts from April to June, harvesting can begin as of the third year after plantation. In relation with its earliness, special requirements of asparagus involve soil, precipitation and light and temperature conditions. During the harvesting period, its heat optimum is $+19^{\circ} \mathrm{C}$, but $\pm 14{ }^{\circ} \mathrm{C}$ does not cause irreversible damage to the spears (Fehérné 2005). Dean (1999) determined the heat threshold of growth of asparagus at $10{ }^{\circ} \mathrm{C}$. Asparagus prefers temperate climatic conditions, its optimum root and shoot growth s realised between 18 and $29{ }^{\circ} \mathrm{C}$ (Brenna et al. 2011). In contrast, according to Dean (1999), heat threshold of growth of shoots is between 24.5 and $33{ }^{\circ} \mathrm{C}$. In his studies, maximum spear growth was observed at $30{ }^{\circ} \mathrm{C}\left(0.51 \mathrm{~cm} \mathrm{~h}^{-1}\right.$ growth). There was a close correlation between daily temperature and spear yield but no statistically confirmed correlation was established. Wilson et al. (1999) found that the heat threshold of asparagus growth was $7.1{ }^{\circ} \mathrm{C}$ based on the analysed data, but different heat threshold values were determined at each test sites. Based on studies carried out in the United States, a developmental heat threshold of $6.7^{\circ} \mathrm{C}$, while in Japan $4.8^{\circ} \mathrm{C}$ was found with significant 
variety effect. Bouwkamp and McCully (1975) determined the heat threshold at $4.4{ }^{\circ} \mathrm{C}$, while Blumenfield et al. (1961) set this value at $7.2{ }^{\circ} \mathrm{C}$.

Asparagus tolerates drought, but under intensive cultivation circumstances, proper and balanced water supply is important for economic growth, which, in many cases can only be achieved by irrigation. The most suitable soil for cultivation is sandy soil with loose texture, which is free of perennial weeds, stones and impermeable soil layers, so it is easier to harvest higher quality and more straight spears. In addition to water supply and soil properties, nutrient supply is also an important cultivation technology factor. The most suitable soil for cultivation is sandy loam soil with an ideal $\mathrm{pH}$ of between 6.5 and 7.5, and the soil is free of stones, impermeable soil layers and perennial weeds $(\mathrm{Ku}$ 2006). Asparagus belongs to nutrient sensitive crops. To produce $1 \mathrm{t}$ of blanched asparagus, $30 \mathrm{~kg} \mathrm{~N}, 12 \mathrm{~kg} \mathrm{P}_{2} \mathrm{O}_{5}$, $36 \mathrm{~kg} \mathrm{~K}_{2} \mathrm{O}, 3.6 \mathrm{~kg} \mathrm{Mg}$ and $2.1 \mathrm{~kg}$ Ca nutrient is required. Nitrogen absorption is considered the most dynamic, which might last from mid-April to the end of June. In contrast, phosphorus and potassium uptake is much slower; it could be constant even until the end of August (Laczkó 2005, Fehérné 2005, 2009).

\section{MATERIAL AND METHODS}

The examinations have been carried out at the 2011 established asparagus plantation of the University of Debrecen Institutes for Agricultural Research and Educational Farm Research Institutes of Nyíregyháza. The plantation was carried out with a row spacing of $180 \mathrm{~cm}$, and plant spacing of $25 \mathrm{~cm}$, with a plant density of 22300 plants hectare ${ }^{-1}$. The soil of the trial area is typically a good condition humous sandy soil $\left(\mathrm{K}_{\mathrm{A}} 30\right)$ with low acidity ( $\mathrm{pH}$ 6.71) and medium humus content $[1.23 \%(\mathrm{~m} / \mathrm{m})]$ (Table 1$)$.

Table 1

The most important soil parameters on the experimental site of the asparagus (Nyíregyháza, 2015)

\begin{tabular}{|c|c|c|}
\hline Parameter & Result & Unit \\
\hline $\mathrm{pH}_{\mathrm{KCl}}$ & 6.71 & \\
\hline Compaction with Arany method $\left(\mathrm{K}_{\mathrm{A}}\right)$ & 30 & \\
\hline Water-soluble salts & 0.02 & $\%(\mathrm{~m} / \mathrm{m})$ \\
\hline All carbonate content in $\mathrm{CaCO}_{3}$ expressed & 0.417 & $\%(\mathrm{~m} / \mathrm{m})$ \\
\hline Humus content & 1.23 & $\%(\mathrm{~m} / \mathrm{m})$ \\
\hline AL-soluble $\mathrm{P}_{2} \mathrm{O}_{5}$ & 175 & $\mathrm{mg} \mathrm{kg}^{-1}$ \\
\hline Al-soluble $\mathrm{K}_{2} \mathrm{O}$ & 169 & $m g \mathrm{~kg}^{-1}$ \\
\hline $\mathrm{KCl}$-soluble $\mathrm{NO}_{3}{ }^{-}+\mathrm{NO}_{2}{ }^{-}-\mathrm{N}$ & 15.7 & $\mathrm{mg} \mathrm{kg}^{-1}$ \\
\hline AL-soluble $\mathrm{Na}$ & 40.6 & $\mathrm{mg} \mathrm{kg}^{-1}$ \\
\hline KCl-soluble Mg & 50.7 & $m g \mathrm{~kg}^{-1}$ \\
\hline $\mathrm{KCl}$-soluble $\left(\mathrm{SO}_{4}\right) 2^{+}-\mathrm{S}$ & 1.62 & $\mathrm{mg} \mathrm{kg}^{-1}$ \\
\hline KCl-EDTA soluble Mn & 42.5 & $\mathrm{mg} \mathrm{kg}^{-1}$ \\
\hline $\mathrm{KCl}$-EDTA soluble $\mathrm{Zn}$ & 2.95 & $\mathrm{mg} \mathrm{kg}^{-1}$ \\
\hline KCl-EDTA soluble $\mathrm{Cu}$ & 1.83 & $\mathrm{mg} \mathrm{kg}^{-1}$ \\
\hline
\end{tabular}

In the course of the trial, the asparagus hybrid Grolim was examined, which is a $100 \%$ male, Dutch bred hybrid. This hybrid has one of the earliest harvesting periods. Its spears are thick the heads are tight. In field conditions, a trial area of 16 medium plots has been established, where each plot has a size of $36 \mathrm{~m}^{2}$. There were four nutriment supply variants: in addition to the untreated control $40 \mathrm{t} \mathrm{ha}^{-1}$ manure, $40 \mathrm{t}$ $\mathrm{ha}^{-1}$ sheep compost fertilizer and $40 \mathrm{t} \mathrm{ha}^{-1}$ stable manure equivalent fertilizer have been applied. In terms of weather, five years of harvesting have been compared to the evaluation of precipitation data.

The meteorological data were measured with the AgroSense meteorological station and its substations. In the trial area from $1^{\text {st }}$ March to $30^{\text {th }}$ June, the following amounts of precipitation were recorded: $231.5 \mathrm{~mm}$ in $2013,119.9 \mathrm{~mm}$ in $2014,109.8 \mathrm{~mm}$ in 2015, $194.2 \mathrm{~mm}$ and $249.5 \mathrm{~mm}$ until October 2016. In 2015 , there was a significant lack of precipitation (only $109.8 \mathrm{~mm}$ precipitation fell from March to June) in the area, which already had a negative effect on the development of the plants in early spring. In 2017, there was $249.5 \mathrm{~mm}$ of precipitation from March to June, which was the highest amount of precipitation during the growing period within the analysed five years, but its distribution was very hectic. In terms of the analysed months, it exceeded $60 \mathrm{~mm}$ in April and $110 \mathrm{~mm}$ in June (Figure 1 ).

In addition to the development of precipitation data, air and soil temperatures are the most determinant in the spring emergence of asparagus spears. 2013, 2015, 2016 and 2017 are can be considered average in terms of air temperature, however in 2014 it was observed that March was warmer than the average, which could result in earlier harvesting (Figure 2).

In our examinations, the beginning of vegetative development was experienced upon the steady existence of $10{ }^{\circ} \mathrm{C}$ of average soil temperature in the case of the Grolim asparagus hybrid. The beginning of spear harvesting and the length of the harvesting period are both influenced by the beginning and dynamics of spring development. Soil heat units required for the vegetative development of spears have been examined by means of the method of Bouwkamp and Mccully (1975) and Blumenfield et al. (1961) in all five years of harvesting, which provides important information for harvesting practice. For the statistical analysis of yield results, Microsoft Office Excel and SPSS software have been utilised. For statistical reliability analyses, a significance level of $5 \%$ has been determined. 
Figure 1: Amount of precipitation on the trial areas (Nyíregyháza, 2013-2017)

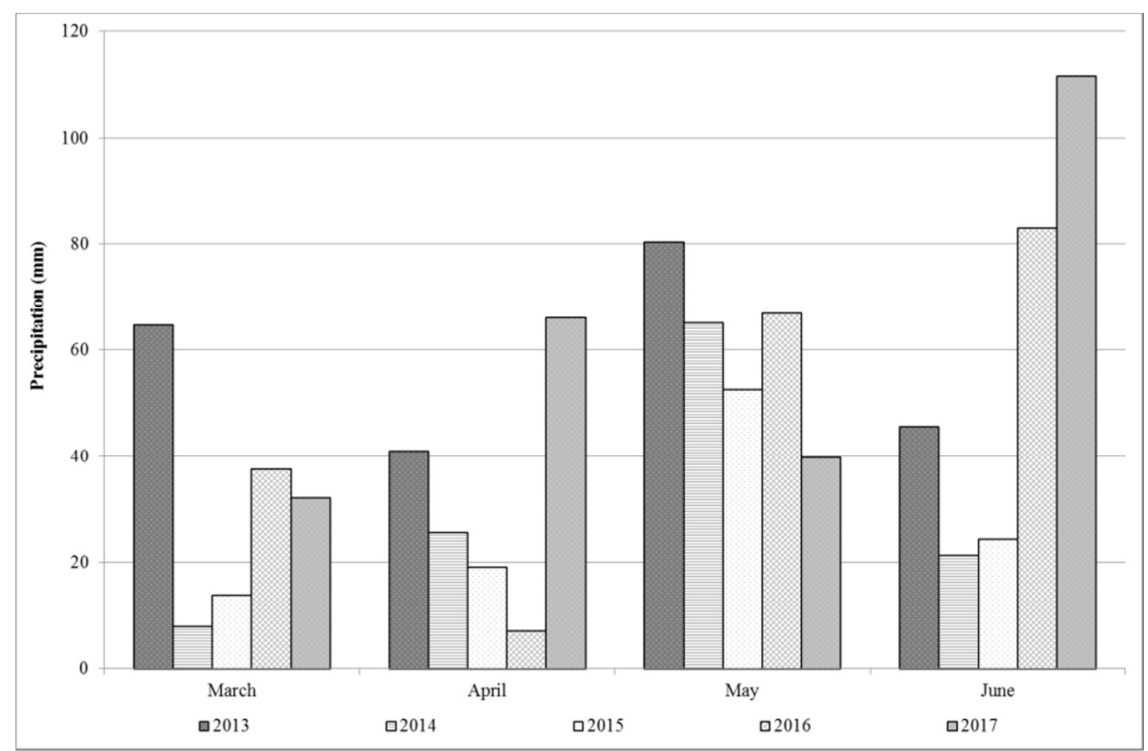

Figure 2: Changes of temperature on the trial areas (Nyíregyháza, 2013-2017)

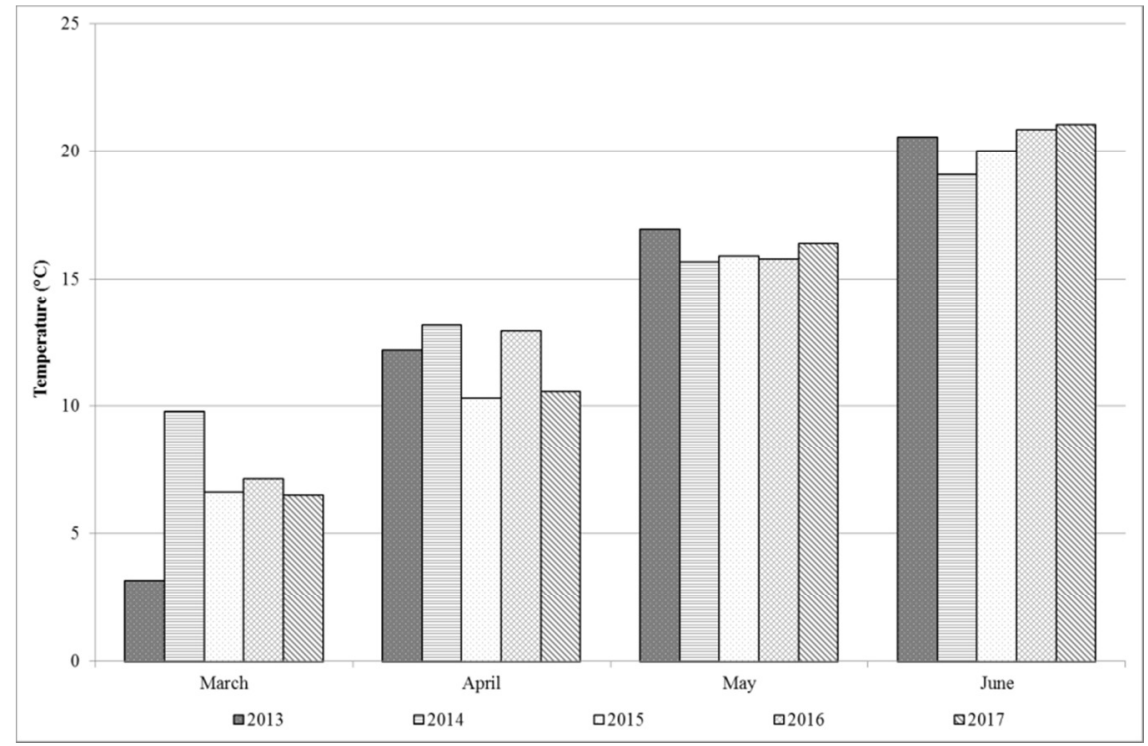

\section{RESULTS}

In the course of my research the effect of different nutriment supply methods have been analysed on the spear yield of Grolim asparagus hybrid during the period of 2013-2017. As a basis of the study, the first 20 days of harvesting have been analysed every year. The determining parameters of the harvesting periods are shown in detail in Table 2.

The main data of Grolim asparagus harvesting period (Nyíregyháza, 2013-2017)

\begin{tabular}{lccccc}
\hline \multicolumn{1}{c}{ Main data } & \multicolumn{5}{c}{ The Grolim asparagus harvesting period (day/month/year) } \\
\hline Soil temperature has reached $10{ }^{\circ} \mathrm{C}$ & 19.04 .2013 & 02.03 .2014 & 12.04 .2015 & 01.04 .2016 & 30.03 .2017 \\
Emergence of the first spear & 25.04 .2013 & 25.03 .2014 & 15.04 .2015 & 08.04 .2016 & 05.04 .2017 \\
Beginning of harvesting & 28.04 .2013 & 28.03 .2014 & 18.04 .2015 & 11.04 .2016 & 09.04 .2017 \\
End of harvesting & 17.05 .2013 & 16.04 .2014 & 07.05 .2015 & 30.04 .2016 & 28.04 .2017 \\
\hline Period of harvesting & 20 & 20 & 20 & 20 & 20 \\
\hline
\end{tabular}


For determining the starting period of harvesting, effective heat unit calculation was carried out in terms of air and soil temperature. Effective heat unit based on air temperature resulted on significantly different heat unit data (Table 3). Based on the method of Bouwkamp and Mccully (1975) the effective air temperature sums changed between 174.05 and 204.55 ${ }^{\circ} \mathrm{C}$, while on the basis of the growth heat threshold determined by Blumenfield et al. (1961) the effective heat unit changed between 97.69 and $143.90{ }^{\circ} \mathrm{C}$.

Table 3

Development of effective heat unit calculated based on air temperature $\left({ }^{\circ} \mathrm{C}\right)$ in the case of the Grolim asparagus hybrid (Nyíregyháza, 2013-2017)

\begin{tabular}{rcc}
\hline Year & $\begin{array}{c}\text { According to } \\
\text { Bouwkamp and Mccully }\end{array}$ & $\begin{array}{c}\text { Based on } \\
\text { Blumenfield et al. } \\
(1975)\end{array}$ \\
\hline 2013 & 204.55 & $(1961)$ \\
2014 & 193.55 & 105.90 \\
2015 & 174.05 & 143.90 \\
2016 & 199.40 & 102.80 \\
2017 & 200.25 & 107.38 \\
\hline
\end{tabular}

For the statistical evaluation of the effects of treatments, Tukey-test was utilised, where the chosen significance level was 5\% (Table 5). The analysis showed that significant difference is recorded compared to the control treatment in the case of compost treatment, stable manure treatment and artificial fertilizer treatment in terms of the effect on spear yield.

In the case of the determination of effective heat unit required until the emergence of harvestable spears determined with the help of the average soil temperature values, clear and similar results were obtained in different production years, indicating a lower deviation of the effective heat unit determination based on soil temperature (Table 4). According to Bouwkamp and Mccully (1975), the effective air temperature sums based on the soil temperature varied between 73.2 and $108.8{ }^{\circ} \mathrm{C}$, while based on the heat threshold of Blumenfield et al. (1961), the effective heat unit based on soil temperature ranged from 35.30 to $48.90{ }^{\circ} \mathrm{C}$.

Development of effective soil temperature based on soil temperature $\left({ }^{\circ} \mathrm{C}\right)$ in the case of the Grolim asparagus hybrid (Nyíregyháza, 2013-2017)

\begin{tabular}{lcc}
\hline Year & $\begin{array}{c}\text { According to } \\
\text { Bouwkamp and Mccully }\end{array}$ & $\begin{array}{c}\text { Based on } \\
\text { Blumenfield et al. } \\
(1975)\end{array}$ \\
\hline 2013 & 108.10 & $(1961)$ \\
2014 & 73.20 & 35.30 \\
2015 & 102.34 & 39.50 \\
2016 & 88.00 & 43.28 \\
2017 & 102.95 & 48.90 \\
\hline
\end{tabular}

During the five years of harvesting, in the control treatment, compared to 2013 and 2014, a nearly 50\% decrease in terms of yield was recorded. In 2017, the highest crop yield was achieved by fertilizer treatment $(14.01 \mathrm{~kg} / \mathrm{plot} / \mathrm{harvesting}$ period), followed by sheep manure compost $(13.03 \mathrm{~kg} / \mathrm{plot} / \mathrm{harvesting}$ period $)$, stable manure treatment $(10.92 \mathrm{~kg} / \mathrm{plot} / \mathrm{harvesting}$ period) and finally control treatment $(2.63 \mathrm{~kg} / \mathrm{plot} /$ harvesting period) (Figure 3).

Figure 3: Effect of production year and fertilizer methods on the yield of Grolim asparagus hybrid (Asparagus officinalis L.) (Nyíregyháza, 2013-2017)

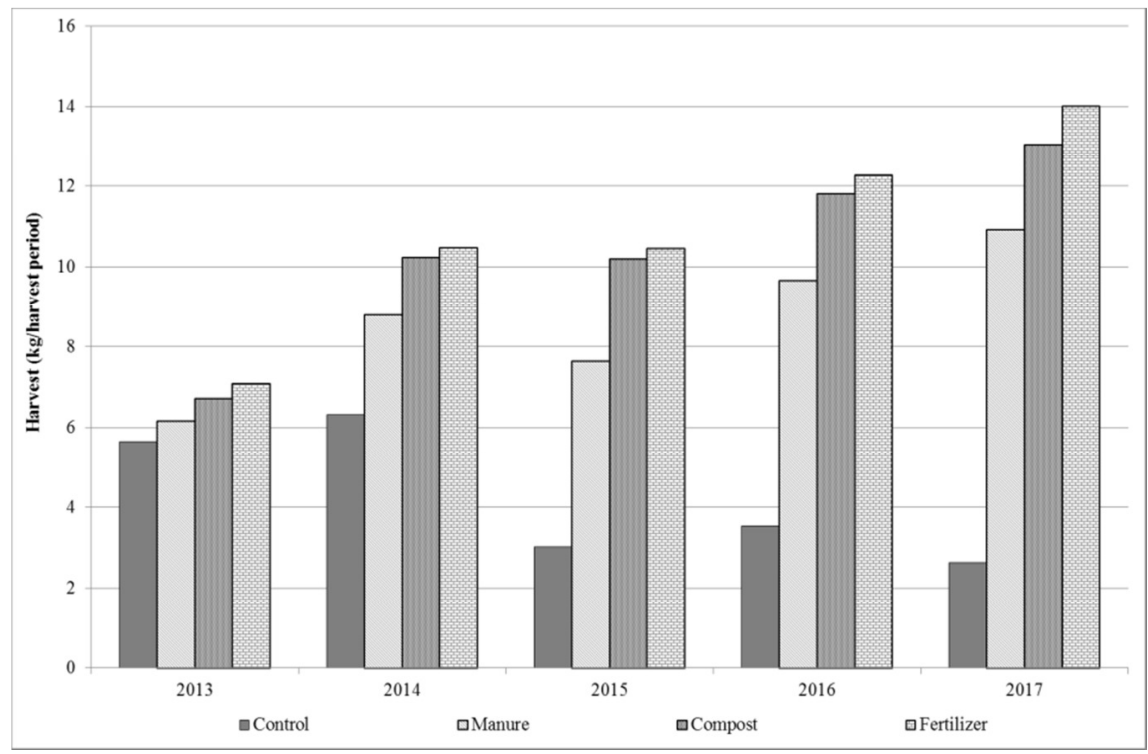


The statistical analysis of the effect of the different fertilization methods on the yield of Grolim asparagus hybrid (Nyíregyháza, 2013-2017)

\begin{tabular}{|c|c|c|c|c|c|}
\hline & & \multicolumn{4}{|c|}{ Grolim asparagus hybrid } \\
\hline & & Control & Manure & Compost & Fertilizer \\
\hline \multirow{4}{*}{$\begin{array}{l}\text { Grolim } \\
\text { asparagus } \\
\text { hybrid }\end{array}$} & Control & 0 & $-4.39000(*)$ & $-6.16000(*)$ & $-6.61800(*)$ \\
\hline & Manure & $4.390000(*)$ & 0 & -1.77000 & -2.22800 \\
\hline & Compost & $6.16000(*)$ & 1.77000 & 0 & --.45800 \\
\hline & Fertilizer & $6.61800(*)$ & 2.22800 & 0.45800 & 0 \\
\hline
\end{tabular}

Note: * significantly different groups, significant at level 0.05 .

\section{DISCUSSION OF THE RESULTS, CONCLUSIONS}

Based on my studies, it can be concluded that the highest yield was achieved in the artificial fertilizer treatment in all five harvesting periods. Smaller yield increase resulted by the sheep manure compost and stable manure treatments. In the five examined harvesting periods, the control treatment had the lowest spear yield. The effect of various nutrient treatments manifested itself in the decrease yields deviations, which clearly demonstrates the yield stabilising effect of nutrient supply. This is also important for asparagus because moderate fertilization reactions occur in the case of perennial plants, but the sensitivity of the plant to nutrient supply in the case of asparagus has become clear based on the test results.

It can also be stated that soil temperature is one of the most important factors in the emergence time of spears. Our observations have shown that the emergence of spears is expectable once soil temperature rises steadily above $10{ }^{\circ} \mathrm{C}$. In the course of calculating the effective heat unit, it was established that in the case of the Grolim hybrid and assuming a $4.4{ }^{\circ} \mathrm{C}$ heat threshold, the emergence of spears was experienced upon reaching an effective heat unit of $105.90{ }^{\circ} \mathrm{C}$ in $2013,143.90{ }^{\circ} \mathrm{C}$ in $2014,102.80{ }^{\circ} \mathrm{C}$ in 2015, 107.38 ${ }^{\circ} \mathrm{C}$ in 2016 and $97.68{ }^{\circ} \mathrm{C}$ in 2017. Assuming a growth threshold of 7.2, the emergence of spears was experienced upon reaching an effective heat unit of in $35.30{ }^{\circ} \mathrm{C}$ in $2013,39.50{ }^{\circ} \mathrm{C}$ in 2014 , $43.28{ }^{\circ} \mathrm{C}$ in $2015,48.90{ }^{\circ} \mathrm{C}$ in 2016 and $46.34{ }^{\circ} \mathrm{C}$ in 2017. Our studies have confirmed the production year dependence of asparagus spear yield. In 2016 and 2017 , early warming and a favourable amount of precipitation during the harvesting period resulted in a significant increase in terms of spear yield in all three nutrient treatments. During the five years of harvesting. In 2017, the highest crop yield was achieved by fertilizer treatment $(14.01 \mathrm{~kg} / \mathrm{plot} / \mathrm{harvesting}$ period), followed by sheep manure compost $(13.03 \mathrm{~kg} / \mathrm{plot} / \mathrm{harvesting}$ period), stable manure treatment $(10.92 \mathrm{~kg} / \mathrm{plot} /$ harvesting period) and finally control treatment (2.63 $\mathrm{kg} / \mathrm{plot} / \mathrm{harvesting}$ period). The analysis showed that significant difference is recorded compared to the control treatment in the case of compost treatment, stable manure treatment and artificial fertilizer treatment in terms of the effect on spear yield.

\section{ACKNOWLEDGEMENT}

Our analysis have been carried out in the scope of the „Supported by the ÚNKP-17-3 New National Excellence Program of the Ministry of Human Capacities” and „Supported by the NTP-EFÖ-P-15 Scholarships providing unique development of the Ministry of Human Capacities".

\section{REFERENCES}

Blumefield, D. K.-Meinken, K. W.-Le Compte, S. B. (1961): A field study of asparagus growth. Proceeding of American Society Horticultural Science. 77: 386-392.

Bouwkamp, J. C.-McCully, J. E. (1975): Effects of simulated and no-selective mechanical harvesting on spear emergence of Asparagus officinalis L. Scienta Horticulturae. 3. 2: 157-162.

Brenna, A.-Michael, C.-Steven, K.-Richard, S.-Timothy, H.Trevor, S. (2011): Asparagus production is California. UC Vegetable Research \& Information Centre. 1-6.

Cerne, M.-Kacjan Marsic, N. (2002): Asparagus. Sodobnokmetijstvo. 35. 5: 207-211.

Dean, B. B. (1999): The effect of temperature on asparagus spear growth an correlation of heat units accumulated in the field with spear yield. Acta Horticulturae. 479: 289-296.
Drost, D. T. (1997): Asparagus. [In: Wien, H. C. (ed.) The Physiology of Vegetable Crops.] CAB International. Wantage. 621-649.

Fehér B.-né (2005): A spárga termesztése. Mezőgazda Kiadó. Budapest. 113-121.

Fehér B.-né (2009): Spárga. [In: Hodossi et al. (szerk.) Zöldségtermesztés szabadföldön.] Mezőgazda Kiadó. Budapest. 349-356.

$\mathrm{Ku}$, Y. G. (2006): The kinetics of spear growth and asparagus productivity: control by environmental and internal factors. $\mathrm{PhD}$ dissertation. Massey University. 17-27.

Laczkó B. (2005): Családi gazdaságokból az Unióba. Káposztafélék, spárga és görögdinnye exportra. Szaktudás Kiadó Ház. Budapest. 77-81. 
Pressman, E.-Schaffer, A. A.-Compton, D.-Zamski, E. (1993): Seasonal changes in the carbohydrate content in two cultivars of asparagus. Scientia Hort. 53: 149-155.

Wilson, D. R.-Cloughley, C. G.-Sinton, S. M. (1999): Model of the influence of the temperature on the elongation rate of asparagus spears. Acta Horticulturae. 479: 297-304.
Wilson, D. R.-Cloughley, C. G.-Sinton, S. M. (2002): Aspirenz: A decision support system for managing root carbohydrate in asparagus. X. International Asparagus Symphosium. Naiigata. Japan. ISHS Acta Horticulturae. 589: 51-58. 